\title{
Epidemiology of non-exclusive breastfeeding behavior (study in the working area of primary health care Margorejo Pati regency)
}

\author{
Emawati Fatima, Lintang Dian Saraswati*, Praba Ginandjar, Dwi Sutiningsih \\ Department of Epidemiology and Tropical Disease, Faculty of Public Health, Diponegoro University
}

\begin{abstract}
Non-exclusive breastfeeding is defined as the provision of food or fluids in addition to drugs, vitamins, and minerals to infants before the age of 6 months. Exclusive breastfeeding for infants is seen to prevent and cure stunting and other forms of malnutrition. Primary Health Care (PHC) Margorejo is the health center with the lowest exclusive breastfeeding coverage in Pati Regency in 2017 and 2018. The purpose of this study was to analyze the factors related to the behavior of non-exclusive breastfeeding in the working area of the PHC Margorejo in Pati Regency. This study uses a case control method. The research sample consisted of 70 consisting of 35 cases and 35 controls. The research targets were mothers who have 6-11 months old infants in the working area of the PHC Margorejo. Bivariate analysis showed a low level of maternal knowledge $(p=0.008)$, negative maternal attitudes $(p=0.022)$, and the absence of support from health workers $(\mathrm{p}=0.002)$ related to non-exclusive breastfeeding behavior. Low level knowledge of mothers, negative attitude of mothers, and the absence of support from health workers are all factors related to the behavior of non-exclusive breastfeeding in the working area of PHC Margorejo in Pati Regency.
\end{abstract}

Keywords. Non-exclusive breastfeeding, epidemiology, behavior

\section{Background}

Non-exclusive breastfeeding is defined as the provision of food or fluids in addition to drugs, vitamins, and minerals to infants before the age of 6 month [1]. Non-exclusive breastfeeding has a negative impact on infants. Non-exclusively breastfed babies will experience nutritional deficiencies that will affect growth or improper height. One growth disorder that occurs due to malnutrition is stunting [2].

Non-exclusive breastfeeding is also an important cause of infant morbidity [3]. Nonexclusive breastfeeding contributes up to $45 \%$ of deaths due to neonatal infection, $30 \%$ of deaths due to diarrhea, $18 \%$ of deaths due to acute breathing among toddlers in developing

* Corresponding author: lintang.saraswati@live.undip.ac.id 
countries, and is responsible for $10 \%$ of the burden of illness in infants [4]. As many as $96 \%$ of all infant deaths, ie 1.24 million, occurred during the first six months of life due to non-exclusive breastfeeding which is much higher in Asia and Africa. Non-exclusive breastfeeding accounts for $55 \%$ of diarrhea deaths and $53 \%$ of acute respiratory death in the first six months of life [5].

Primary Health Care Margorejo is the health center with the lowest exclusive breastfeeding coverage in Pati Regency for 2 years in a row which is $36.63 \%$ in 2017 and $33.9 \%$ in 2018. The coverage is far below the Pati Regency strategic Plan's 2017 target of $51 \%$ and in 2018 55\%. Whereas in 2016, the Primary Health Care Margorejo was able to exceed the strategic plan target with exclusive breastfeeding coverage of $66.24 \%$ [6-8]. Low exclusive breastfeeding coverage has the possibility of affecting the incidence of stunting. In the same year, the incidence of stunting in Primary Health Care Margorejo reached $24.5 \%$ in 2017 and $15.9 \%$ in 2018 while the strategic plan target was $<8 \%$.

Behavioral epidemiology studies behavioral and lifestyle factors related to disease risk, factors that influence behavior, and the application of knowledge to develop effective interventions to change behavior. According to Bloom, behavior provides the greatest contribution in determining health status so that behavioral epidemiology analyzes behavioral factors as both protective and disease risk factors [9-11].

In the working area of Primary Health Care Margorejo, the risk factors for nonexclusive breastfeeding behavior are unknown, so further research is needed. Therefore, to increase the coverage of exclusive breastfeeding, it is necessary to know risk factors for the behavior of non-exclusive breastfeeding in the working area of the Primary Health Care Margorejo, Pati Regency.

\section{Methods}

The study was conducted in December 2019-May 2020. The research location was conducted in the working area of the Primary Health Care Margorejo, Pati Regency. This type of research used in this research is observational analytic research that is analyzing the behavior factors of non-exclusive breastfeeding. The design approach chosen is case control. The research method used is a quantitative method using a questionnaire. The independent variable in this study is the level of knowledge, attitudes, and support of health workers. While the dependent variable used in this study is the behavior of non-exclusive breastfeeding.

The population of this study was all mothers who had babies aged 6-11 months in the working area of the Primary Health Care Margorejo as many as 110 people. Case population in this study are mothers who have babies aged 6-11 months with non-exclusive breastfeeding behavior as many as 75 people. The control population in this study was mothers who had babies aged 6-11 months with exclusive breastfeeding behavior of 35 people.

Case samples in this study are mothers who have babies aged 6-11 months who are in the working area of the Primary Health Care (PHC) Margorejo and listed in the PHC Margorejo data provide non-exclusive breastfeeding. The control sample in this study is mothers who have babies aged 6-11 months who are in the working area of the Primary Health Care (PHC) Margorejo and are listed in the PHC data that provides exclusive breastfeeding. The control sampling technique is done by the total sampling method. While the case sampling is done by simple random sampling, that is by giving a number to each subject on the list that has been owned and then selecting 35 sample cases by using a random sample generator application.

The level of knowledge referred to in this study is the knowledge and understanding of respondents about exclusive breastfeeding including the definition, type, composition, 
nutrition, and benefits of exclusive breastfeeding. The attitude of the mother referred to respondents' responses to statements regarding the practice of exclusive breastfeeding. The support of health workers referred to in this study is the respondent's perception of the presence or absence of positive influence provided by health workers in the form of advice, assistance, and information that can support breastfeeding.

\section{Result}

Table 1. Age of Infant

\begin{tabular}{lcc}
\hline Age of Infant & \multicolumn{2}{c}{$\begin{array}{c}\text { Total } \\
(\mathrm{n}=70)\end{array}$} \\
\cline { 2 - 3 } & $\mathrm{f}$ & $\%$ \\
\hline 6 months & 10 & 14.3 \\
7 months & 11 & 15.7 \\
8 months & 15 & 21.4 \\
9 months & 15 & 21.4 \\
10 months & 8 & 11.4 \\
11 months & 11 & 15.7 \\
\hline
\end{tabular}

The majority of respondents have babies aged 8 and 9 months. The average age of the respondent's baby is 8.5 months. The age of the youngest respondent's baby is 6 months while the oldest is 11 months (Table 1). Among the case group, the most prelacteal drinks were formula milk $(60.0 \%)$ whereas the most prelacteal food given was instant porridge (17.1\%) (Table 2).

Table 2. Non-exclusive breastfeeding behavior

\begin{tabular}{lrr}
\hline \multicolumn{1}{c}{$\begin{array}{c}\text { Intake of prelacteal drinks and } \\
\text { foods }\end{array}$} & \multicolumn{2}{c}{$\begin{array}{c}\text { Total } \\
(\mathrm{n}=35)\end{array}$} \\
\cline { 2 - 3 } & \multicolumn{1}{c}{$\mathrm{f}$} & \multicolumn{1}{c}{$\%$} \\
\hline Prelacteal drinks & 21 & 60.0 \\
Formula milk & 19 & 54.3 \\
Water & 0 & 0 \\
Tea & 0 & 0 \\
Starch water & 1 & 2.9 \\
Green bean water & 4 & 11.4 \\
Honey water & & \\
Prelacteal foods & 1 & $2, .9$ \\
White rice & 0 & 0 \\
Steamed rice & 0 & 0 \\
Rice cake & 2 & 5.7 \\
Porridge & 6 & 17.1 \\
Instant porridge & 1 & 2.9 \\
Bread & 5 & 14.3 \\
Biscuits & 3 & 8.6 \\
Banana & 1 & 2.9 \\
Potato & & \\
\hline
\end{tabular}


Table 3. Frequency Distribution of Non-Exclusive Breastfeeding

\begin{tabular}{lrr}
\hline \multicolumn{1}{c}{ Drinks/Foods Prelacteal } & \multicolumn{2}{c}{ Total } \\
& \multicolumn{2}{c}{$(\mathrm{n}=35)$} \\
\cline { 2 - 3 } & $\mathrm{f}$ & $\%$ \\
\hline Given by mother & 33 & 94.3 \\
Given by someone else & 2 & 5.7 \\
\hline
\end{tabular}

Table 4. Bivariate Analysis

\begin{tabular}{|c|c|c|c|c|c|}
\hline \multirow[t]{3}{*}{ Variables } & \multicolumn{4}{|c|}{ Breastfeeding Behavior } & \multirow[t]{3}{*}{$P$} \\
\hline & \multicolumn{2}{|c|}{$\begin{array}{c}\text { Non- } \\
\text { exclusive } \\
(\mathrm{n}=35)\end{array}$} & \multicolumn{2}{|c|}{$\begin{array}{l}\text { Exclusive } \\
\quad(n=35)\end{array}$} & \\
\hline & $f$ & $\%$ & $f$ & $\%$ & \\
\hline \multicolumn{6}{|l|}{ Level of Knowledge } \\
\hline Low & 22 & 66.7 & 11 & 33.3 & 0.008 \\
\hline High & 13 & 35.1 & 24 & 64.9 & \\
\hline \multicolumn{6}{|l|}{ Mother's attitude } \\
\hline Negative & 16 & 45.7 & 7 & 20.0 & 0.022 \\
\hline Positive & 19 & 54.3 & 28 & 80.0 & \\
\hline \multicolumn{6}{|c|}{ Support of Health Workers } \\
\hline Not supportive & 21 & 72.4 & 8 & 27.6 & 0.002 \\
\hline Supportive & 14 & 34.1 & 27 & 65.9 & \\
\hline
\end{tabular}

The most prelacteal foods/drinks in the case group were given by mothers $(94.3 \%)$ (Table 3). A low level of maternal knowledge $(\mathrm{p}=0.008)$, negative maternal attitudes $(\mathrm{p}=$ $0.022)$, and the absence of support from health workers $(\mathrm{p}=0.002)$ related to non-exclusive breastfeeding behavior (Table 4).

\section{Discussion}

This study found an association between maternal knowledge related to exclusive breastfeeding and exclusive breastfeeding behavior. The results of this study are in line with the study of Senja and Helmie in 2017 which stated that there was a relationship (pvalue $=0.013$ ) between the level of knowledge of mothers with exclusive breastfeeding at the Health Post of Air Kubang Village, Air Naningan District, Tanggamus District [12]. The results of the study are not in line with the research of Nur Alam Fajar, et al in 2018 
who found no relationship ( $\mathrm{p}$-value $=0.120$ ) between the knowledge of exclusive breastfeeding and exclusive breastfeeding behavior [13].

Lack of mother's knowledge about exclusive breastfeeding will form a negative assessment, so that it will change the behavior of mothers in breastfeeding. Conversely, a good mother's knowledge about breastfeeding will form a positive assessment which will then encourage the mother to give exclusive breastfeeding. When encountering problems in the breastfeeding process, the level of knowledge the mother has also helps the decisionmaking process. Mothers who have a good level of knowledge will first try to overcome the problem in exclusive breastfeeding instead of directly switching to formula milk because mothers understand that exclusive breastfeeding has many benefits for both mother and baby. Mothers who have good knowledge understand that breastfeeding is a form of mother's responsibility in meeting the nutritional needs of babies.

Health workers must be more active in disseminating exclusive breastfeeding information with the help of breastfeeding motivators and assistance to nursing mothers by health cadres so that the level of knowledge of mothers increases. Counseling is not only done by the lecture method, but can also be added with media leaflets, power points, and videos. Counseling is also not limited to social activities such as the Empowerment of Family Welfare, social gathering, and so on, but can also be done through social media such as WhatsApp, Facebook, and so on.

This study found a relationship between maternal attitudes and exclusive breastfeeding behavior. The results of this study are in line with research conducted by Senja and Helmie in 2017 which stated that there was a relationship ( $p$-value $=0.001$ ) between mother's attitude and exclusive breastfeeding at the Air Kubang Village Health Post, Air Naningan District, Tanggamus Regency [12]. The results of the study are not in line with the research of Rodhiya and Agustiansyah in 2018 which did not find a relationship ( $p$-value $=0.933$ ) between maternal attitudes and exclusive breastfeeding [14].

The attitude about exclusive breastfeeding by respondents is a factor that determines a person's willingness or readiness to give exclusive breastfeeding [15]. In this study, respondents who had the wrong knowledge about exclusive breastfeeding or believed certain myths which ultimately formed a negative attitude. Some myths that are believed by mothers are: babies aged 0-6 months will be hungry if only breastfed because mothers think babies cry more often if only breastfed, giving bananas to infants 0-6 months is good for launching bowel movements, breastfeeding can relax breast because it is always drunk, and giving honey to babies 0-6 months is good for increasing stamina and health. Some respondents also still agree with the feeding of infants in the event of selapanan cultural reasons. Coupled with the lack of support from health workers finally perpetuates the negative attitude of mothers about exclusive breastfeeding due to the absence of alignment by providing correct information from local health workers.

Primary Health Care as a health service provider should provide some kind of training for residents who are seconded as breastfeeding motivators and health cadres. It is intended to equalize the correct perception of exclusive breastfeeding between motivators, cadres and health workers. So armed with a correct understanding of exclusive breastfeeding, health cadres and breastfeeding motivators can correct the myths that are not right about breastfeeding in the community.

Support of health workers is physical and psychological comfort, attention, appreciation, and assistance received by individuals from health workers [16]. In this study found a relationship between support of health workers with exclusive breastfeeding behavior. This is in line with the study of Esa, et al in 2017 which revealed a relationship ( $p$-value $=0,000$ ) between support of health workers and exclusive breastfeeding [16]. The results of a literature review conducted by Jordana, et al in Brazil in 2014 of 18 literatures concluded that health workers need to be trained to work to promote breastfeeding, either 
by health schools or health service administrators, to consolidate multiprofessional teams committed to maternal and infant health [17].

One of the supports of health workers is manifested in the form of exclusive breastfeeding. Exclusive breastfeeding counseling aims to ensure that mothers get good information on the definition, content, benefits, and breastfeeding techniques so that mothers can plan to breastfeed exclusively since pregnancy [18]. The role of health workers in relation to exclusive breastfeeding is very important, especially to deal with the promotion of formula milk and the provision of prelacteal food and drinks. Support of health workers can be done during pregnancy checks. Help, advice, and support continue after the mother returns from antenatal care [19].

The lack of support from health workers in this study is shown by the large number of respondents, especially the case group, who feel they have never received information such as the definition and benefits of exclusive breastfeeding from health workers. Some respondents also obtained information from books, the internet, and social media which had weaknesses whose truth could not be ascertained. In the case group it was also seen that only half the respondents felt motivated to provide exclusive breastfeeding from health workers. The lack of role of health workers is related to the mother's decision to provide non-exclusive breastfeeding.

The lack of program evaluation also causes the primary health care to not be able to measure the quality of breastfeeding promoters who come from the community. It is necessary to do a kind of competency test so that there are promoter standards so that it can be seen which promoter taxes have not met the standards. Promoters who do not meet the standards can be given training in order to achieve the specified standards.

\section{Conclusion}

The level of maternal knowledge is low, negative maternal attitudes, and the absence of support from health workers are factors related to the behavior of non-exclusive breastfeeding in the working area of Primary Health Care Margorejo Pati Regency.

\section{References}

1. Berhanu, M., Zemene, W. \& Mekonnen, M. Prevalence and associated factors of nonexclusive breastfeeding to infants within the first 6 months in gondar town, northwest ethiopia, 2014. Adv. Nurs. 2015, 1-7 (2015).

2. Sarinengsih, Y. Hubungan pemberian ASI eksklusif dengan kejadian stunting pada balita usia 1-5 tahun di puskesmas sukahening kecamatan sukahening kabupaten tasikmalaya. J. Ilmu Kesehat. 13, 109-117 (2019).

3. Diallo, F. B., Bell, L., Moutquin, J.-M. \& Garant, M.-P. The effects of exclusive versus non-exclusive breastfeeding on specific infant morbidities in conakry (guinea). Pan Africa Med. J. 2, 1-9 (2009).

4. Mekuria, G. \& Edris, M. Exclusive breastfeeding and associated factors among mothers in debre markos, northwest ethiopia : a cross-sectional study. Int. Breastfeed. J. 10, 1-7 (2015).

5. Tewabe, T. et al. Exclusive breastfeeding practice and associated factors among mothers in motta town, east gojjam zone, amhara regional state, ethiopia, 2015: a cross-sectional study. Int. Breastfeed. J. 12, 1-7 (2017).

6. Dinas Kesehatan Kabupaten Pati. Cakupan ASI Eksklusif 2016. (2016).

7. Dinas Kesehatan Kabupaten Pati. Cakupan ASI Eksklusif 2017. (2017). 
8. Dinas Kesehatan Kabupaten Pati. Cakupan ASI Eksklusif 2018. (2018).

9. Kuh, D. \& Shlomo, Y. Ben. A life course approach to chronic disease epidemiology. (OUP Oxford, 2004).

10. Sallis, J. F. et al. Behavioral epidemiology: a systematic framework to classify phases of research on health promotion and disease prevention. Ann. Behav. Med. 22, 294 295 (2000).

11. Saraswati, L. D. Buku ajar dasar epidemiologi. (LP2MP Universitas Diponegoro, 2015).

12. Putri, S. R. \& Yenie, H. Faktor-faktor yang berhubungan dengan pemberian ASI eksklusif pada salah satu desa di kabupaten tanggamus. J. Keperawatan XIII, 221225 (2017).

13. Fajar, N. A., Purnama, D. H., Destriatania, S. \& Ningsih, N. Hubungan pemberian ASI eksklusif dalam perspektif sosial budaya di kota palembang. J. Ilmu Kesehat. Masy. 9, 226-234 (2018).

14. Fricilia, R. \& Agustiansyah. Faktor-faktor yang mempengaruhi ibu dalam pemberian ASI eksklusif kepada bayi di puskesmas sebangkau kecamatan pemangkat kabupaten sambas. Pontianak Nutr. Jounal 01, 2-6 (2018).

15. Yanuarini, T. A., Rahayu, D. E. \& Prahitasari, E. Hubungan pengetahuan dengan sikap ibu dalam pemberian ASI eksklusif di wilayah kerja puskesmas pranggang kabupaten kediri. J. Ilmu Kesehat. 3, 1-9 (2014).

16. Windari, E. N., Dewi, A. K. \& Siswanto. Pengaruh dukungan tenaga kesehatan terhadap pemberian ASI eksklusif di wilayah kerja puskesmas sisir kelurahan sisir kota batu. J. Issues Midwifery 1, 19-24 (2017).

17. Almeida, J. M. de, Luz, S. de A. B. \& Ued, F. da V. Support of breastfeeding by health professionals : integrative review of the literature. Rev. Paul. Pediatr. (English Ed. 33, 355-362 (2015).

18. Rosita, N. A. Peran dukungan orang tua faktor yang paling berpengaruh terhadap pemberian ASI eksklusif. Unnes J. Public Heal. 5, (2016).

19. Arintasari, F. Faktor-faktor yang berhubungan dengan pemberian ASI eksklusif di puskesmas tegalrejo yogyakarta tahun 2015. J. Med. Respati 11, 42-51 (2016). 